\title{
PHYTOCHEMICAL SCREENING AND BACTERICIDAL POTENCY OF JUSTICIA ADHATODA AGAINST CLINICAL PATHOGENS
}

\author{
SELVARANI $\mathbf{M}^{1 *}$, JEYASIMGA ${ }^{2}$ \\ ${ }^{1}$ Department of Zoology, Sree Sevugan Annamalai College, Devakottai, Tamil Nadu, India. ${ }^{2}$ Department of Biotechnology, \\ V. V. Vanniaperumal College for Women (Autonomous), Virudhunagar, Tamil Nadu, India. Email: selvarani.msrani@gmail.com
}

Received: 19 September 2019, Revised and Accepted: 23 July 2020

\section{ABSTRACT}

Objective: Increasing prevalence of bacterial resistance has made an important public health issue in the modern world. Nowadays, many research efforts have been directed toward the development of drugs from medicinal plants for the treatment of diseases caused by microorganisms. Hence, the present attempt has been made to evaluate the bactericidal potency of traditional medicinal plant, Justicia adhatoda against selected clinical pathogens.

Methods: Leaf extracts of $J$. adhatoda were subjected to standard phytochemical analyses by qualitative color tests to confirm the presence of active Phytoconstituents. Bactericidal potency of the leaf extracts of J. adhatoda was assessed by growth inhibition zone against Bacillus cereus, Escherichia coli, Klebsiella pneumoniae, Pseudomonas aeruginosa, and Staphylococcus aureus. Sensitivity of the tested bacterial strains was also checked with standard reference antibiotic vancomycin.

Results: Qualitative phytochemical analyses revealed the presence of alkaloids, terpenoids, flavonoids, tannins, steroids, anthraquinones, saponins, resins, glycosides, and phenols. Fourier-transform infrared spectrum confirmed the presence of phytochemicals belong to various functional groups such as alkenes, alkanes, aliphatic and aromatic amines, aldehydes, esters, alcohols, and phenols. Results on bactericidal efficacy demonstrated that solvents used in the present experiment showed higher activity in the order ethanol $>$ ethyl acetate $>$ chloroform $>$ diethyl ether $>$ methanol $>$ acetone $>$ water. Leaf extracts of $J$. adhatoda showed the higher activity for different clinical pathogens in the order of $P$. aeruginosa $>B$. cereus $>E$. coli $>$ K. pneumoniae $>$ S. aureus. Among the tested bacterial pathogens, $B$. cereus exhibited maximum susceptibility (18.33 \pm 0.94 mm) toward ethyl acetate extract. The maximum activity index $(2.67 \pm 0.42)$ and fold area increase $(6.31 \pm 2.24)$ were also observed against $B$. cereus for ethyl acetate extract.

Conclusion: The present study revealed that $J$. adhatoda has broad spectrum of antibacterial activity and a potential source of antibacterial agents that could be useful for the control of infectious diseases.

Keywords: Justicia adhatoda, Phytochemical screening, Bactericidal potency, Activity index, Fold area increase.

(C) 2020 The Authors. Published by Innovare Academic Sciences Pvt Ltd. This is an open access article under the CC BY license (http://creativecommons. org/licenses/by/4. 0/) DOI: http://dx.doi.org/10.22159/ajpcr.2020.v13i10.29851

\section{INTRODUCTION}

Increased resistance of microorganisms to conventional drugs has necessitated the search for new efficient and cost effective ways for the control of infectious diseases [1]. This would trigger immense interest in the search for new antimicrobial drugs of plant origin [2]. The primary benefits of using plant derived medicines are that they are relatively safer than synthetic alternatives offering profound therapeutic benefits and more affordable treatment [3]. It is also expected that plant extracts showing target sites on microorganisms other than those used by antibiotics. Therefore, it will be active against drug-resistant microbial pathogens [4]. Moreover, the drugs obtained from plants are less toxic; side effects are scanty and also cost effective. For medicinal purposes, the antimicrobial activity of substances derived from plant extracts has been recognized and widely studied for many years $[5,6]$. The medicinal values attributed to plants are a function of the bioactive phytochemical constituents. Phytochemical constituents are natural bioactive compounds present in plants that are used as food and medicine to protect against illness and to maintain human health [7]. Phytochemicals have antioxidant or hormone like effect which helps in fighting against many diseases including cancer, heart diseases, diabetes, high blood pressure, and preventing the formation of carcinogens on their target tissues [8].

Justicia adhatoda is a medicinally important plant belonging to the family Acanthaceae that is native of South Asia. It is commonly known as Vasaka or Malabar nut. It is a highly valuable Ayurvedic medicinal plant used to treat cold, cough, asthma, and tuberculosis [9]. This medicinal plant is exclusively studied for its active components such as quinazoline, alkaloids, vasicine, vasicinone, deoxyvasicine, oxyvasicine, maiontone, and other essential oils [10]. The major alkaloids of the plant, vasicine, and vasicinone have been found to be biologically active. The source of the drug "Vasaka" is well known in the indigenous system of medicine for its beneficial effects, particularly in bronchitis [11]. Leaves and roots of this plant are efficacious in coughs, arthritis, diarrhoea, and dysentery as well as having the best chemostatic quality. Leaves are antiinflammatory, analgesic effective in skin disorders [12]. Because of many medicinal properties possessed by J. adhatoda, the main objective of this study was to evaluate the bactericidal potency of the leaf extracts of $J$. adhatoda against clinical pathogens.

\section{MATERIALS AND METHODS}

\section{Materials}

Pure and analytical grade chemicals were used in the current study. Acetone, ethanol, methanol, chloroform, ethyl acetate, diethyl ether, nutrient agar, nutrient broth, Mueller-Hinton agar, agar-agar, and standard antibiotic disk Vancomycin were purchased from HiMedia (P) Ltd, Mumbai, India. It was used as starting materials without further purification.

\section{Methods}

Collection and preparation of leaf materials

Healthy, disease free and mature J. adhatoda leaves were collected from V.V.Vanniaperumal College for Women campus. The leaves were washed 
thoroughly with running tap water and then with sterile distilled water to remove the dirt before drying process. Then, the leaves were dried in shade at room temperature for a week to remove moisture content. The leaves were regularly examined to check any fungal growth or rotting. The dried leaf materials were powdered using mixer grinder to obtain fine particle size. Finally, the powdered sample was stored at room temperature for further studies.

\section{Preparation of leaf extracts}

$2.5 \mathrm{~g}$ of powdered leaf sample was taken in air tight bottles. To this, add $50 \mathrm{ml}$ of different solvents such as acetone, ethanol, methanol, chloroform, ethyl acetate, diethyl ether, and distilled water. After 2 days, the contents were stirred well thoroughly and filtered through Whatman no.1 filter paper. Then, the filtrate was collected and stored in sterile bottles at $4^{\circ} \mathrm{C}$ until further use.

\section{Phytochemical screening of J. adhatoda leaf extracts}

Freshly prepared leaf extracts of $J$. adhatoda were subjected to standard phytochemical analyses $[13,14]$ to find out the presence of various phytochemical constituents such as alkaloids, terpenoids, flavonoids, tannins, steroids, anthraquinones, saponins, resins, glycosides, and phenols.

\section{Test for alkaloids (Mayer's test)}

$1 \mathrm{ml}$ of $J$. adhatoda leaf extract was added with 2-3 drops of Mayer's reagent (dissolve $1.36 \mathrm{~g}$ of mercuric chloride in $60 \mathrm{ml}$ water and pour into the solution containing $5 \mathrm{~g}$ of potassium iodide in $100 \mathrm{ml}$ water). The appearance of cream color or pale yellow color precipitate indicated the presence of alkaloids.

\section{Test for terpenoids (Knollar's test)}

$1 \mathrm{ml}$ of leaf extract was mixed with $2 \mathrm{ml}$ of chloroform. To this, add $1 \mathrm{ml}$ of conc. sulfuric acid carefully to form a layer. Formation of reddish brown coloration at the interface indicated positive results for the presence of terpenoids.

\section{Test for flavonoids (sodium hydroxide test)}

$1 \mathrm{ml}$ of leaf extract was dissolved in diluted sodium hydroxide and then hydrochloric acid was added. The solution color changed from yellow to colorless indicated the presence of flavonoids.

\section{Test for tannins (lead acetate test)}

To $1 \mathrm{ml}$ of leaf extract, few drops of $1 \%$ lead acetate solution were added. Formation of yellowish precipitate indicated the presence of tannins.

\section{Test for steroids (chloroform test)}

$1 \mathrm{ml}$ of leaf extract was dissolved in $10 \mathrm{ml}$ of chloroform, and then add equal volume of conc. sulfuric acid by sides of the test tube. The upper layer turned red and sulfuric acid layer showed yellow with green fluorescence. This indicated the presence of steroids in the leaf extracts.

\section{Test for anthroquinone (free anthraquinones test)}

$0.5 \mathrm{ml}$ of leaf extract was mixed with $10 \mathrm{ml}$ of benzene and then the content was filtered using Whatman no.1 filter paper. To this filtrate, $5 \mathrm{ml}$ of $10 \%$ ammonia solution was added and shaken well. Formation of pink, red or violet color indicated the presence of anthraquinone derivative.

\section{Test for saponins (foam test)}

$3 \mathrm{ml}$ of leaf extract was diluted with $20 \mathrm{ml}$ of distilled water and shaken well for about $15 \mathrm{~min}$. Formation of stable foam suggested the presence of saponins.

\section{Test for resins (sodium hydroxide test)}

$0.5 \mathrm{ml}$ of leaf extract was treated with caustic soda $(\mathrm{NaOH})$. Development of red color indicated the presence of resins.
Test for glycosides (Keller-Kilian's test)

To $1 \mathrm{ml}$ of leaf extract, add $2 \mathrm{ml}$ of glacial acetic acid containing 2 drops of $2 \%$ ferric chloride solution. The mixture was poured into another test tube containing $2 \mathrm{ml}$ of conc. sulfuric acid. A brown ring was seen at the interphase indicated the presence of glycosides.

\section{Test for phenols (ferric chloride test)}

To $1 \mathrm{ml}$ of leaf extract, add $2 \mathrm{ml}$ of $2 \%$ ferric chloride solution. Formation of blue or green color indicated the presence of phenols

Fourier-transform infrared (FT-IR) analysis

To identify the functional groups present in the compounds of J. adhatoda leaves, IR-spectral analysis was performed using Shimadzu FT-IR 8300 instrument. The spectra were recorded from 500 to $4500 \mathrm{~cm}^{-1}$.

\section{Antibacterial screening of $\boldsymbol{J}$. adhatoda leaf extracts}

\section{Culture and maintenance of the test organisms}

The following bacterial cultures of Bacillus cereus, Escherichia coli, Klebsiella pneumoniae, Pseudomonas aeruginosa, and Staphylococcus aureus were procured from the Department of Microbiology, V. V. Vanniaperumal College for Women, Virudhunagar. The procured cultures were reconfirmed by Gram staining and biochemical testing methods. After confirmation, all the bacterial strains were grown on nutrient agar plates and maintained in the nutrient agar slants at $4{ }^{\circ} \mathrm{C}$. The bacterial strains were inoculated in nutrient broth and incubated overnight at room temperature for antibacterial screening.

\section{Assay to evaluate bactericidal potency}

The antibacterial potency of $J$. adhatoda leaf extracts was evaluated using agar-well diffusion method. Approximately $20 \mathrm{ml}$ of sterile Muller-Hinton agar was poured into sterile Petri plates and allowed to set. Plates were then seeded with $0.5 \mathrm{ml}$ of overnight incubated bacterial culture using a sterile glass rod (L-rod). The plates were allowed to dry. For doing agar well diffusion method, wells were made on the plate with the aid of a sterile hole puncture ( $6 \mathrm{~mm}$ diameter). $50 \mu \mathrm{l}$ of $J$. adhatoda leaf extracts were poured into the respective wells. The plates thus prepared were left at room temperature for $10 \mathrm{~min}$, allowing the diffusion of the extracts into the agar. Then, the plates were placed in the incubator at $37^{\circ} \mathrm{C}$ for $24 \mathrm{~h}$. The antibacterial activity of the leaf extracts was assessed by growth inhibition zone surrounding the well. The zone of inhibition was measured and expressed in millimeters $(\mathrm{mm})$. The assay was performed in triplicates.

\section{Assessment of activity index and fold area increase}

Activity index [15,16] and fold area increase [17] were calculated by comparing the resultant inhibition zones of leaf extracts with the standard reference antibiotic using the following formula:

$$
\begin{gathered}
\text { Activity index }(\mathrm{AI})=\frac{\text { Inhibitory zone of leaf extracts }}{\text { Inhibitory zone of reference antibiotic }} \\
\text { Fold area increase }(\mathrm{FI})=\mathrm{b}^{2}-\mathrm{a}^{2} / \mathrm{a}^{2}
\end{gathered}
$$

Where, $\mathrm{a}$ and $\mathrm{b}$ refer to the inhibitory zone of reference antibiotic and leaf extracts, respectively.

\section{RESULTS AND DISCUSSION}

Phytochemical screening of bioactive compounds in leaf extracts of $J$. adhatoda

The leaf extracts of $J$. adhatoda were screened for the presence of various bioactive compounds by qualitative color tests and the results are given in Table 1.

Successful prediction of bioactive compounds from plant materials is highly depends on the type of solvents used for extraction. The yield 
Table 1: Qualitative phytochemical analyses of J. adhatoda leaf extracts

\begin{tabular}{|c|c|c|c|c|c|c|c|}
\hline Compounds & $\begin{array}{l}\text { Acetone } \\
\text { extract }\end{array}$ & Ethanol extract & $\begin{array}{l}\text { Methanol } \\
\text { extract }\end{array}$ & $\begin{array}{l}\text { Chloroform } \\
\text { extract }\end{array}$ & $\begin{array}{l}\text { Ethyl acetate } \\
\text { extract }\end{array}$ & $\begin{array}{l}\text { Diethyl ether } \\
\text { extract }\end{array}$ & $\begin{array}{l}\text { Aqueous } \\
\text { extract }\end{array}$ \\
\hline Alkaloids & - & + & - & + & - & - & + \\
\hline Terpenoids & - & + & + & - & - & + & + \\
\hline Flavonoids & + & + & - & - & - & + & + \\
\hline Tannins & - & + & - & - & + & - & + \\
\hline Steroids & + & + & + & + & - & - & + \\
\hline Anthraquinones & + & - & - & + & + & - & - \\
\hline Resins & + & - & - & + & - & - & - \\
\hline Glycosides & - & + & - & - & + & - & + \\
\hline Phenols & - & + & + & + & - & - & - \\
\hline
\end{tabular}

+: Present, -: Absent, J. adhatoda: Justicia adhatoda

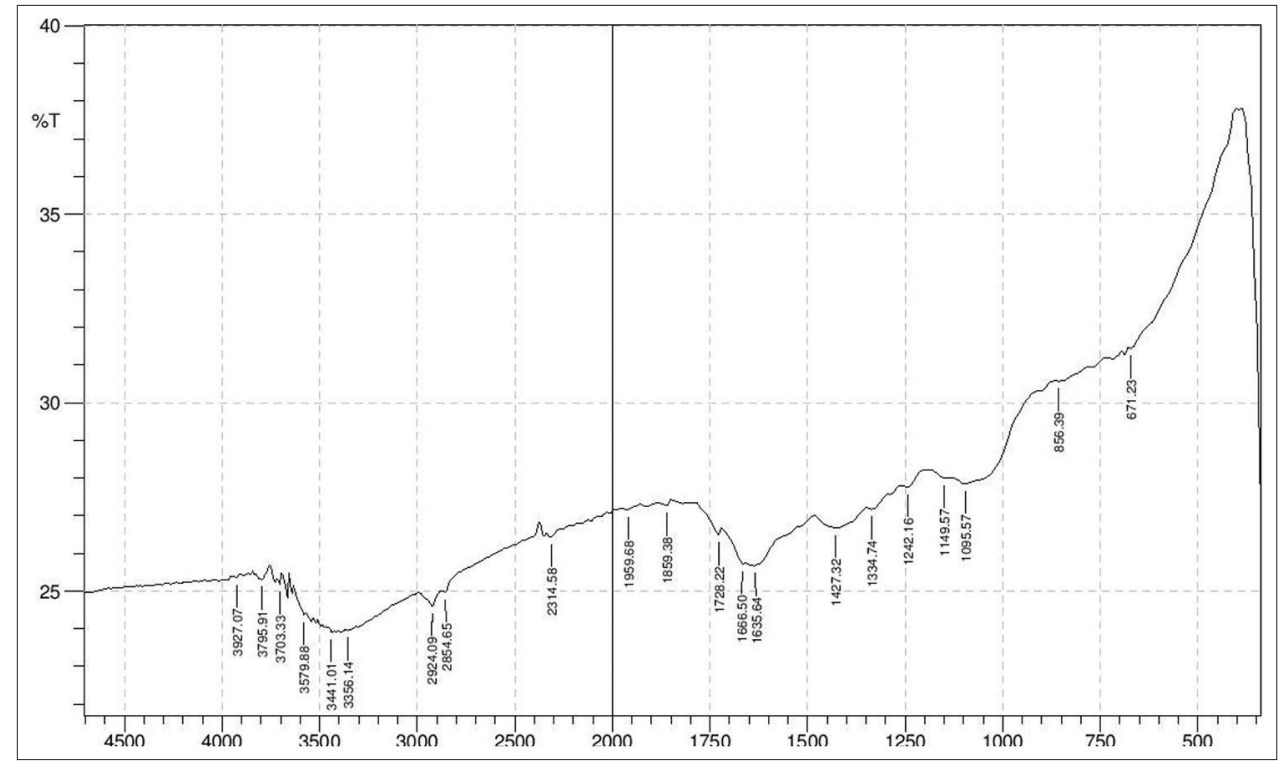

Fig. 1: Fourier-transform infrared spectrum of Justicia adhatoda leaves

of extraction mainly depended on solvents, time, and temperature of extraction as well as chemical nature of the sample [18]. Solvents such as aqueous mixture of methanol, ethanol, and acetone are the most recommended and effective one $[19,20]$. In similar to this, the solvents selected for the extract preparation in the present study are good and effective. The results on phytochemical screening showed the presence of various bioactive compounds such as alkaloids, terpenoids, flavonoids, tannins, steroids, anthraquinones, saponins, resins, glycosides, and phenols in some of the extracts. The ethanolic and the aqueous extracts were rich in alkaloids, terpenoids, flavonoids, tannins, steroids, saponins, glycosides, and phenols than in other extracts. While the diethyl ether extract was poor in their phytochemical contents, since it contains only terpenoids, flavonoids, and saponins. Similar type of bioactive components were identified [21] in the leaf extract of J. adhatoda and their results revealed the presence of various components such as alkaloids, anthraquinones, flavonoids, saponins, phytosterols, triterpenoids, and poly-phenols. The diversity of phytochemicals found in the $J$. adhatoda leaf extract suggested that the selected medicinal plant could be served as a source of useful drug.

\section{FT-IR analysis}

Fig. 1 illustrates the FT-IR spectrum of $J$. adhatoda leaves. The spectrum revealed the presence of several absorption bands for various functional groups ranging from 500 to $4500 \mathrm{~cm}^{-1}$. The main bioactive compounds found in the adhatoda plants are vasicine, vasicinone, vasicol, vasicinol, vasicinolone, etc. [22].
The resultant functional groups attributed to absorption bands are listed in Table 2. The characteristic peak appeared at $671.23 \mathrm{~cm}^{-1}$ and $856.39 \mathrm{~cm}^{-1}$ is due to alkene $\mathrm{C}-\mathrm{H}$ bending vibrations. The bands observed at $1095.57 \mathrm{~cm}^{-1}, 1149.57 \mathrm{~cm}^{-1}$, and $1246.16 \mathrm{~cm}^{-1}$ are ascribed to $\mathrm{C}-\mathrm{N}$ stretching frequencies of aliphatic amines. The presence of aromatic amines and aromatics showed the stretching bands at $1334.74 \mathrm{~cm}^{-1}$ and $1427.32 \mathrm{~cm}^{-1}$, respectively. The peaks at $1666.50 \mathrm{~cm}^{-1}$ and $1728.32 \mathrm{~cm}^{-1}$ indicated the presence of $\mathrm{C}=\mathrm{C}$ and $\mathrm{C}=\mathrm{O}$ stretching vibrations. The functional groups of esters and allene showed characteristic bands at $1859.38 \mathrm{~cm}^{-1}, 2314.58 \mathrm{~cm}^{-1}$, and $1959.68 \mathrm{~cm}^{-1}$. The absorption bands at $2584.65 \mathrm{~cm}^{-1}$ and $2924.09 \mathrm{~cm}^{-1}$ indicated the presence of alkanes containing $\mathrm{C}-\mathrm{H}$ stretching vibrations. The IR bands noticed at $3356.14 \mathrm{~cm}^{-1}, 3441.01 \mathrm{~cm}^{-1}$, and $3579.88 \mathrm{~cm}^{-1}$ are due to $\mathrm{O}-\mathrm{H}$ stretching frequencies of alcohols and phenols. The peaks seen at $3703.33 \mathrm{~cm}^{-1}, 3795.91 \mathrm{~cm}^{-1}$, and $3927.07 \mathrm{~cm}^{-1}$ are attributed to aromatic $\mathrm{CH}$ group/heterogram containing $\mathrm{C}-\mathrm{C}$ group.

\section{Bactericidal potency of $J$. adhatoda leaf extract}

The antibacterial effect of various leaf extracts (acetone, ethanol, methanol, chloroform, ethyl acetate, diethyl ether, and aqueous extracts) of J. adhatoda was determined by the presence of inhibitory zone. The antibacterial activity of the leaf extracts varied according to various organisms tested. Similarly, Tilak et al. [23] found out that different extracts of same plant exhibit different antibacterial activity against the similar bacterium. The inhibition zone ranged between $6.00 \pm 0.00 \mathrm{~mm}$ and $18.33 \pm 0.94 \mathrm{~mm}$ (Table 3 ). 
The given results clearly depicted that all the tested leaf extracts showed profound antibacterial efficacy against the selected pathogenic strains. The maximum zone of inhibition of $18.33 \pm 0.94 \mathrm{~mm}$ was noticed for ethyl acetate extracts against $B$. cereus, whereas, the minimum inhibition zone $(6.00 \pm 0.00 \mathrm{~mm})$ was seen against $K$. pneumoniae for methanolic leaf extract. Overall, the ethanolic extract of $J$. adhatoda had strong growth inhibitory effects on all tested pathogens, followed by ethyl acetate, chloroform, diethyl ether, methanol, acetone, and aqueous extracts. The findings from the present study indicated that the antimicrobial activity may vary with the nature of the solvents used for extraction [24]. The presence of different phytochemicals such as alkaloids, terpenoids, flavonoids, tannins, steroids, saponins, glycosides, and phenols in the leaf extracts could be related to the broad spectrum activity. The antibacterial activity possessed by the leaf extracts is due to the presence of bioactive compounds in the plants [25]. Sankar et al. [18] reported that the antibacterial activity of the plant extracts might be attributed due to the presence of bioactive

Table 2: Functional groups present in the compounds of J. adhatoda leaves

\begin{tabular}{lll}
\hline Wavenumber $\left(\mathbf{c m}^{-\mathbf{1}}\right)$ & $\begin{array}{l}\text { Functional } \\
\text { group }\end{array}$ & $\begin{array}{l}\text { Name of the } \\
\text { functional group }\end{array}$ \\
\hline $671.23,856.39$ & $\mathrm{C}-\mathrm{H}$ & Alkene \\
$1095.57,1149.57,1242.16$ & $\mathrm{C}-\mathrm{N}$ & Aliphatic amines \\
1334.74 & $\mathrm{C}-\mathrm{N}$ & Aromatic amines \\
1427.32 & $\mathrm{C}-\mathrm{C}$ & Aromatics \\
1635.64 & $\mathrm{~N}-\mathrm{H}$ & Amines \\
1666.50 & $\mathrm{C}=\mathrm{C}$ & Alkenes \\
1728.22 & $\mathrm{C}=\mathrm{O}$ & Aldehydes \\
$1859.38,2314.58$ & $\mathrm{O}-\mathrm{C}=\mathrm{O}$ & Esters \\
1959.68 & $\mathrm{C}=\mathrm{C}=\mathrm{C}$ & Allene \\
$2584.65,2924.09$ & $\mathrm{C}-\mathrm{H}$ & Alkanes \\
$3356.14,3441.01,3579.88$ & $\mathrm{O}-\mathrm{H}$ & Alcohols, phenols \\
\hline
\end{tabular}

compounds such as tannins, phenolic compounds, polyphenols, and flavonoids. Among these bioactive compounds, phenolics were the most important active compounds against bacteria [26]. The results obtained from bactericidal effect of $J$. adhatoda leaf extracts were compared with the standard reference antibiotic disk vancomycin. It revealed that the calculated activity value of leaf extracts was higher than 1 (AI >1), which means that all the tested bacterial pathogens in the present experiment showed very strong inhibitory action than the reference antibiotic (Table 4). The maximum activity index value $(2.67 \pm 0.42)$ was obtained against $B$. cereus using ethyl acetate extracts. Inhibitory potency of the tested extracts could be mostly considered as important when comparing the antibacterial activity of the tested clinical pathogens with the reference antibiotics [2].

In accordance to this, bactericidal effect exhibited by J. adhatoda leaf extracts with the standard reference antibiotic vancomycin in the present experiment demonstrated the inhibitory potency of the tested leaf extracts as the calculated activity value was higher than 1 . Fold area increase of $J$. adhatoda leaf extract with reference to standard antibiotic against selected clinical pathogens as noticed by an increase in diameter of inhibition zone and the results are given in Table 5. Among the tested bacterial pathogens, B. cereus showed highest increase in fold area $(6.31 \pm 2.24)$ using ethyl acetate extract, followed by $K$. pneumoniae $(4.05 \pm 1.55)$ and $E$. coli $(3.45 \pm 1.05)$ using ethanolic extracts. S. aureus and P. aeruginosa exhibited maximum fold area increase for the ethanolic $(1.53 \pm 0.85)$ and chloroform $(1.30 \pm 0.87)$ leaf extracts, respectively. Overall results on bactericidal potency exhibited by J. adhatoda leaf extracts demonstrated that Gram-negative bacterial strains were more susceptible to all the extracts used than Grampositive pathogens. This could be attributed to its cell wall structure. The exact mechanism of antimicrobial activity of plant compounds is not clearly defined. However, multiple dose-dependent pathways have been postulated. These include damage of membrane at bactericidal concentrations of plant compounds as well as loss of energy production which finally lead to cell death [27].

Table 3: Zone of inhibition of leaf extracts of $J$. adhatoda against selected clinical bacterial pathogens

\begin{tabular}{|c|c|c|c|c|c|}
\hline \multirow[t]{3}{*}{ Name of the extract } & \multicolumn{5}{|c|}{ Zone of inhibition (mm) } \\
\hline & \multicolumn{5}{|c|}{ Tested organisms } \\
\hline & B. cereus & E. coli & K. pneumoniae & P. aeruginosa & S. aureus \\
\hline Acetone & $7.33 \pm 0.47$ & $7.67 \pm 1.25$ & $11.33 \pm 1.25$ & $11.67 \pm 2.87$ & $8.00 \pm 0.82$ \\
\hline Ethanol & $10.33 \pm 1.25$ & $14.67 \pm 1.70$ & $13.33 \pm 2.05$ & $12.33 \pm 2.49$ & $13.33 \pm 1.25$ \\
\hline Methanol & $8.00 \pm 0.82$ & $12.00 \pm 1.63$ & $6.00 \pm 0.00$ & $10.33 \pm 2.05$ & $11.00 \pm 2.16$ \\
\hline Chloroform & $11.00 \pm 1.63$ & $12.00 \pm 2.45$ & $8.00 \pm 0.82$ & $14.67 \pm 2.05$ & $11.00 \pm 0.00$ \\
\hline Ethyl acetate & $18.33 \pm 0.94$ & $12.33 \pm 2.05$ & $10.67 \pm 2.49$ & $12.00 \pm 0.82$ & $6.67 \pm 0.94$ \\
\hline Aqueous & $10.00 \pm 2.16$ & $7.00 \pm 0.82$ & $11.00 \pm 0.82$ & $10.00 \pm 2.16$ & $8.00 \pm 0.82$ \\
\hline Standard reference antibiotic vancomycin & $7.00 \pm 0.82$ & $7.00 \pm 0.00$ & $6.00 \pm 0.00$ & $10.00 \pm 1.63$ & $8.67 \pm 0.94$ \\
\hline
\end{tabular}

Each value is the mean \pm SD of triplicate analysis. B. cereus: Bacillus cereus, E. coli: Escherichia coli, K. pneumoniae: Klebsiella pneumoniae, P. aeruginosa: Pseudomonas aeruginosa, S. aureus: Staphylococcus aureus, J. adhatoda: Justicia adhatoda

Table 4: Activity index of leaf extracts of $J$. adhatoda against selected clinical bacterial pathogens

\begin{tabular}{|c|c|c|c|c|c|}
\hline \multirow[t]{3}{*}{ Name of the extract } & \multicolumn{5}{|c|}{ Activity index } \\
\hline & \multicolumn{5}{|c|}{ Tested organisms } \\
\hline & B. cereus & E. coli & K. pneumoniae & P. aeruginosa & S. aureus \\
\hline Acetone & $1.06 \pm 0.13$ & $1.10 \pm 0.18$ & $1.89 \pm 0.20$ & $1.18 \pm 0.29$ & $0.93 \pm 0.05$ \\
\hline Ethanol & $1.52 \pm 0.36$ & $2.10 \pm 0.24$ & $2.22 \pm 0.35$ & $1.29 \pm 0.39$ & $1.57 \pm 0.28$ \\
\hline Methanol & $1.15 \pm 0.02$ & $1.71 \pm 0.23$ & $1.00 \pm 0.00$ & $1.03 \pm 0.04$ & $1.26 \pm 0.11$ \\
\hline Chloroform & $1.57 \pm 0.05$ & $1.71 \pm 0.35$ & $1.33 \pm 0.13$ & $1.50 \pm 0.28$ & $1.29 \pm 0.13$ \\
\hline Ethyl acetate & $2.67 \pm 0.42$ & $1.76 \pm 0.29$ & $1.78 \pm 0.42$ & $1.23 \pm 0.19$ & $0.78 \pm 0.16$ \\
\hline Aqueous & $1.42 \pm 0.20$ & $1.00 \pm 0.11$ & $1.83 \pm 0.13$ & $0.99 \pm 0.07$ & $0.94 \pm 0.14$ \\
\hline
\end{tabular}

Each value is the mean \pm SD of triplicate analysis. B. cereus: Bacillus cereus, E. coli: Escherichia coli, K. pneumoniae: Klebsiella pneumoniae, P. aeruginosa: Pseudomonas aeruginosa, S. aureus: Staphylococcus aureus, J. adhatoda: Justicia adhatoda 
Table 5: Fold area increase of leaf extracts of J. adhatoda against selected clinical bacterial pathogens

\begin{tabular}{|c|c|c|c|c|c|}
\hline \multirow[t]{3}{*}{ Name of the extract } & \multicolumn{5}{|c|}{ Fold area increase } \\
\hline & \multicolumn{5}{|c|}{ Tested organisms } \\
\hline & B. cereus & E. coli & K. pneumoniae & P. aeruginosa & S. aureus \\
\hline Acetone & $0.30 \pm 0.05$ & $0.41 \pm 0.17$ & $0.56 \pm 0.35$ & $0.56 \pm 0.35$ & $0.14 \pm 0.10$ \\
\hline Ethanol & $1.43 \pm 1.15$ & $3.45 \pm 1.05$ & $1.11 \pm 0.49$ & $1.11 \pm 0.49$ & $1.53 \pm 0.85$ \\
\hline Methanol & $0.31 \pm 0.03$ & $1.99 \pm 0.80$ & $0.06 \pm 0.08$ & $0.06 \pm 0.08$ & $0.60 \pm 0.28$ \\
\hline Chloroform & $1.45 \pm 0.16$ & $2.06 \pm 1.20$ & $1.30 \pm 0.87$ & $1.30 \pm 0.87$ & $0.66 \pm 0.32$ \\
\hline Ethyl acetate & $6.31 \pm 2.24$ & $2.19 \pm 1.06$ & $0.54 \pm 0.50$ & $0.54 \pm 0.50$ & $0.36 \pm 0.27$ \\
\hline Aqueous & $1.07 \pm 0.56$ & $0.19 \pm 0.14$ & $0.12 \pm 0.09$ & $0.12 \pm 0.09$ & $0.29 \pm 0.05$ \\
\hline
\end{tabular}

Each value is the mean \pm SD of triplicate analysis. B. cereus: Bacillus cereus, E. coli: Escherichia coli, K. pneumoniae: Klebsiella pneumoniae, P. aeruginosa: Pseudomonas aeruginosa, S. aureus: Staphylococcus aureus, J. adhatoda: Justicia adhatoda

\section{CONCLUSION}

The frequency of life-threatening infections caused by pathogenic microorganisms has increased worldwide. It is becoming an important cause of morbidity and mortality in immune compromised patients particularly in developing countries like our India. Thus, the findings from the present study revealed that J. adhatoda leaf extracts showed varying degrees of antibacterial property against the selected clinical pathogens. Thus, the broad spectrum of antibacterial activity exhibited by J. adhatoda may help to discover new chemical classes of antibiotic substances that could serve as selective agents of infectious disease chemotherapy and control.

\section{ACKNOWLEDGEMENT}

The authors are very grateful to the Principal and the Managing board, V. V. Vanniaperumal College for Women for providing necessary facilities.

\section{AUTHOR'S CONTRIBUTIONS}

The author Dr. M. Selvarani designed the experiment and determined the bactericidal potency of J. adhatoda leaf extracts. Dr. V. Jeyasimga prepared the leaf extracts of $J$. adhatoda and carried out phytochemical analyses. Both the authors prepared and accepted the manuscript.

\section{CONFLICTS OF INTEREST}

The authors declare that there are no conflicts of interest.

\section{REFERENCES}

1. Hidayathulla S, Chandra KK, Chandrashekar KR. Phytochemical evaluation and antibacterial activity of Pterospermum diversifolium Blume. Int J Pharm Pharm Sci 2011;3:165-7.

2. Rashmi P, Mathew L. Antimicrobial activity of leaf extracts of Justicia adhatoda L. in comparision with vasicine. Asian Pac J Trop Biomed 2012;2:1556-60

3. Chopra RN, Nayer SL, Chopra IC. Glossary of Indian Medicinal Plants. New Delhi, India: Council of Scientific and Industrial Research; 1956.

4. Ahmad I, Beg AZ. Antimicrobial and phytochemical studies on Indian medicinal plants against multi-drug resistant human pathogens. J Ethnopharmacol 2001;74:113-23.

5. Mohamed HS, Abdelgadir WS, Almagboul AZ. In vitro antimicrobial activity of anise seed (Pimpinella anisum L.). Int J Adv Res 2015;3:359-67.

6. Hamoud R, Sporer F, Reichling J, Wink M. Antimicrobial activity of a traditionally used complex essential oil distillate (Olbas Tropfen) in comparison to its individual essential oil ingredients. Phytomedicine 2012;19:969-76.

7. Afolabi CA, Ibukun EO, Emmanuel A, Obuotor EM, Farombi EO. Phytoconstituent and antioxidant activity of extract from the leaves of Ocimum gratissimum. Sci Res Essays 2007:2:163-6.

8. Daniel VN, Daniang IE, Nimyel ND. Phytochemical analysis and mineral elements composition of Ocimum basilicum obtained in JOS metropolis, Plateau State, Nigeria. Int J Eng Technol. 2011;11:161-5.

9. Dhankhar S, Kaur R, Ruhil S, Balhara M, Dhankhar S, Chhillar AK. A review on Justicia adhatoda: A potential source of natural medicine.
Afr J Plant Sci 2011:5:620-7.

10. Srivastava S, Verma RK, Subhash MM, Singh C, Kumar S. HPLC determination of vasicine and vasicinone in Adhatoda vasica with photo diode array detection. J Liq Chromatogr Relat Technol 2001;24:153-9.

11. Kumar A, Ram J, Samarth RM, Kumar M. Modulatory influence of Adhatoda vasica Nees leaf extract against gamma irradiation in Swiss albino mice. Phytomedicine 2005;12:285-93.

12. Ilango K, Chitra V, Kanimozhi P, Balaji G. Antidiabetic, antioxidant and antibacterial activities of leaf extracts of Adhatoda zeylanica. Medic (Acanthaceae). J Pharm Sci Res 2009;2:67-73

13. Trease GE, Evans WC. Pharmacognosy. Vol. 14. London: WB Scandars Company Ltd.; 1989. p. 269-300.

14. Sahu M, Vermaand D, Harris K. Phytochemical analysis of the leaf, stem and seed extracts of Cajanus cajan L. (Dicotyledoneae: Fabaceae). World J Pharm Pharm Sci 2014;3:694-733.

15. Singariya P, Kumar P, Mourya KK. Antimicrobial activity of fruit coat (calyx) of Withania somnifera against some multi drug resistant microbes. Int J Biol Pharm Res 2012;3:252-8

16. Selvarani M, Prema P. Evaluation of antibacterial efficacy of chemically synthesized copper and zerovalent iron nanoparticles. Asian J Pharm Clin Res 2013;6:223-7.

17. Shahverdi AR, Fakhimi A, Shahverdi HR, Minaian S. Synthesis and effects of silver nanoparticles on the antibacterial activity of different antibiotics against Staphylococcus aureus and Escherichia coli. Nanomedicine 2007;3:168-71

18. Sankar SG, Thangapandiyan S, Alisha AS, Kumar PS. Phytochemical screening and potential bactericidal efficacy of Annona squamosa leaf extracts. World J Pharm Life Sci 2018;4:144-9.

19. Waterman PG, Mole S. Methodology in ecology. In: Analysis of Phenolic Plant Metabolites. London: Blackwell Science Publications; 1994. p. 66-103.

20. Vairavan S, Thangapandiyan S, Alisha AS. Larvicidal efficacy of Catharanthus roseus leaf extracts against filarial vector Culex quinquefasciatus (Diptera: Culicidae). Int J Pharm Sci Rev Res 2018;51:19-25.

21. Jayapriya G, Shoba FG. Phytochemical analysis, antimicrobial efficacy and determination of bioactive components from leaves of Justicia adhatoda (Linn). Asian J Plant Sci Res 2015;5:43-51.

22. Ahmad S, Garg M, Ali M, Singh M, Athar MD, Ansari SH. A phytopharmacological overview on Adhatoda zeylanica Medic. syn. $A$. vasica (Linn.) Nees. Nat Prod Rad 2009;8:549-54.

23. Tilak R, Punit K, Radha R, Kumar DK. Screening of some medicinal plants for their antimicrobial activities. Int J Pharm Pharm Sci 2016;8:202-6.

24. Kanyanga CR, Munduku KC, Ehata TM, Lumpu NS, Maya MB, Manienga K, et al. Antibacterial and antifungal screening of extracts from six medicinal plants collected in Kinshasa-Democratic Republic of Congo against clinical isolate pathogens. J Pharmacogn Phytother 2014;6:24-32.

25. Hassan MH, Ismail MA, Moharram AM, Shoreit AA. Phytochemical and antimicrobial of latex serum of Calotropis procera and its silver nanoparticles against some reference pathogenic strains. J Ecol Health Environ 2017;5:65-75.

26. Baydar H, Sagdic O, Ozkan G, Karadogan T. Antibacterial activity and composition of essential oils from Origanum, Thymbra and Satureja species with commercial importance in Turkey. Food control 2004;15:169-72.

27. Upadhyay A, Mooyottu S, Yin H, Nair S, Bhattaram V, Venkitanarayanan K. Inhibiting microbial toxins using plant-derived compounds and plant extracts. Medicines (Basel) 2015;2:186-211. 